\title{
The Effects of Paper-based Portfolios and Weblog-based Electronic Portfolios on Limited English Proficiency Students in Writing for Service Industry Course
}

\author{
Raveewan Wanchid ${ }^{1}$ \& Valaikorn Charoensuk ${ }^{1}$ \\ ${ }^{1}$ Department of Languages, King Mongkut's University of Technology North Bangkok, Bangkok, Thailand \\ Correspondence: Raveewan Wanchid, Department of Languages, King Mongkut's University of Technology \\ North Bangkok, Bangkok, Thailand. Email: rwanchid@hotmail.com
}

Received: May 13, 2015 Accepted: August 12, 2015 Online Published: August 16, 2015

doi:10.5539/elt.v8n9p131 URL: http://dx.doi.org/10.5539/elt.v8n9p131

\begin{abstract}
The purposes of this study were to investigate the effects of the use of paper-based and weblog-based electronic portfolios on the writing achievement of limited English proficiency students, to survey the students' attitudes towards the use of the portfolio assessment, and to compare the viewpoints of the students in the control and experimental groups. The study was conducted with 60 second-year hotel and tourism students enrolled in the Writing for the Service Industry course. They had limited English proficiency, as their previous English grades were $\mathrm{C}$ or below in average. The simple random sampling technique was used for subject selection and group assignment. Google's free weblog website (located at www.blogger.com) was used as a tool for creating and developing the students' personal electronic portfolios. At the beginning of the course, the students in the control group and the experimental group were trained in the concept of portfolios, and the purposes, content, and criteria used for assessment were discussed with the students. A writing achievement test and a closed-ended questionnaire were used for the quantitative data collection, while the qualitative data were gathered from the open-ended questions, interviews, and reflection. Descriptive statistics and t-tests were employed for the data analysis. It was found that the effects of the use of paper-based portfolios and weblog-based electronic portfolios on the writing achievement were not significantly different, but some promising results of the use of weblog-based electronic portfoliosfor language learning and assessment are indisputable.
\end{abstract}

Keywords: paper-based portfolios, weblog-based electronic portfolios, limited English proficiency students, writing for service industry

\section{Introduction}

In Thailand, hotel and tourism is one of the major business sectors of the country, and it has an influence on the country's national income and economic. According to the Tourist Authority of Thailand (TAT) in 2014, Thailand is persistently one of the world's most famous destinations that attracts many tourists around the world. With the growing internationalized service industry enterprises and the upcoming economic cooperation of the countries in Southeast Asia or the AEC in 2015, it is not an overstatement to claim that effective English language communication skills will be one of the most desired skills for Thai graduate students to succeed in their professional careers.

Unfortunately, previous studies have shown that Thai students seem to have lower English proficiency compared to the students in other countries in Southeast Asia as Thailand ranks $55^{\text {th }}$ out of 60 countries on the English Proficiency Index, which is the lowest among South-East Asian countries ("Thais' poor English could dim job prospects in ASEAN common market", 2015).

As regards hotel and tourism, previous study has demonstrated that Thai educational institutes have failed to produce graduates that reach the requirements and expectations of the tourism industry (Esichaikul \& Baum, 1998). This failure in fact may be due to several factors, such as obsolete teaching and learning materials for the hotel and service industry, or the limitations of the English teaching methods and assessments (Chen, 2009). Without a doubt, the Thai workforce, especially those working in the service industry sector, will be at risk if their English language skills do not improve. 
In tourism enterprises, English writing is considered an important means of communication for getting ideas or messages across to other business acquaintances (Leong \& $\mathrm{Li}, 2012$ ). Interestingly enough, among the four English skills, writing seems to be the most challenging skill since it requires extensive and specialized instruction and practice (Grabe \& Kaplan, 1996; Hyland, 2003). Apart from the complexity of the writing skill itself, the problems of English writing instruction seem to multiply with limited English proficiency students due to their insufficient English knowledge and practice, negative learning beliefs, and dull learning experiences.

In order to prepare the students for the real world of work, English for specific purpose has a vital role to play to train students in the required English skills for their future career. For ESP writing courses, the types of written texts are different in terms of social contexts, audiences, and the purposes of the different types of written texts. It appears that the concepts of product-based and process-based writing approaches seem to be insufficient to teach the students explicitly the particular structures and grammatical forms of the target texts. Therefore the genre-based approach, according to which writing ability can be achieved through explicit writing instruction (Hyland, 2007), and the teaching-learning cycle suggested by Feez (1998) composed of five main stages-1) building the context, 2) modeling and deconstructing the text, 3) joint construction of the text, 4) independent construction of the text, 5) and linking related texts, are implemented as the core teaching philosophy in the Writing for Service Industry course, which is the focus of this paper. The course objectives are to enhance the students' ability in writing for the business correspondence pertaining to their future work, to increase their confidence in business writing, and to encourage students to be independent learners.

Therefore, the traditional assessment, focusing on students' scores and grades on their writing products or exams while paying less attention to the students' learning progress or improvement is obsolete and cannot support the students' achievement of the course goals. In order to avoid a negative washback, the impact of assessment on language teaching and learning, the conformation of the writing instructional method, course goals and objectives, and learning assessment should be of primary concern (Brown \& Hudson, 1998). Therefore, the traditional testing method seems to be a mismatch the conceptual underpinning of the course.

With less exam-centric assessment, portfolios are considered an alternative method of assessment and are widely used for writing assessment due to their ability to measure cognitive skills and affective attributes of the learners. Previous studies have shown that portfolio-based assessment provides authentic and meaningful collection of student work and accurately demonstrates the achievement or improvement of the students (Ekbatani\& Pierson, 2000; Hamp-Lyons \& Condon, 2000; Lipton, 1997). 1997).

In the Internet age, the influence of computer technology has become an integral part of teaching and learning, so it also changes the form of traditional assessment to electronic forms such as integrating computer-mediated communication. Babaee and Tikoduadua (2013) affirmedthat electronic portolios tend to promote the students' refective ability, collaboration, self-and peer-assessment, and self-regulation. Further, social media and virtual learning for modern learners have grasped many researchers' interest as match the learning styles of generation net students.

As there is increasing attention in using electronic portfolios in EFL worldwide, so its design, development, and evaluation should be thoroughly investigated to maximize its benefits in the EFL context (Aliweh, 2012). Research concerning portfolio at the college and university level is limited, although it is increasing used in colleges and university level (Saad\& Noor, 2007). Little research has been carried out on the use of portfolios in the English course at the university level in Thailand, especially in ESP writing courses. Based on the rationale of the study previously discussed, it is therefore worth the time and effort to investigate the effect of the use of traditional portfolios and weblog-based electronic portfolios with limited-level English proficiency students on their writing achievement and to study the students' attitudes in using the types of portfolios they experience in a writing for the service industry course for learning and assessment.

\section{Literature Review}

\subsection{Portfolio as an Alternative Assessment of Writing Instruction}

Concerning writing instruction, negative results of the traditional testing method have been found, such as the inability to measure cognitive ability and affective contributes, the limits to providing true and rich information about an individual's growth, the cause of students' anxiety and stress, and the lack of students' motivation to evaluate their own learning. As a result, a new form of learning assessment underpinned by the constructivist learning approaches or alternative assessment has been developed, as it is believed that instruction should correspond with the assessment in order to create meaningful and significant learning in a constructivist learning environment in real world situations (Mitchel, 1992). There are many types of alternative assessments, such as oral presentation, peer assessment, and self-assessment, but portfolios seem to be widely used in writing 
instruction for both ESL and EFL contexts. The portfolio is a purposeful collection of the students' work that can examine and measure the individual learner's efforts, progress, and achievement by documenting the process of learning or changes as they occurs in one or more areas over time. In fact, portfolios can be categorized according to the nature of assessment and its main purposes. For example, Cooper and Love (2001) categorized portfolios according to two main types: formative and summative, while Wang (2009) divided portfolios into three main types in line with different purposes: showcase portfolios, collection portfolios, and assessment portfolios. Interestingly enough, the mediums for portfolio development vary due to the influence of technology.

\subsection{Traditional Portfolios and Electronic Portfolios}

The transition from paper-based to electronic based portfolios is increasingly prominent. In the Internet age, computer technology has a vital role to play in English language instruction, so the urge for innovative English language teaching and assessment exists, as the previous research has shown that it has positive effects on the students' learning.

According to Barrett (2006), a portfolio is a collection of work that a learner has collected, selected, organized, reflected upon, and presented to show his or her understanding and growth over time. Additionally, it contains a learner's reflection on the individual pieces of work (artifacts), and an overall reflection on the story that the portfolio tells. Previous studies have confirmed that portfolios are better predictors of students' performance in an authentic situation, improve students' higher order thinking skills (DeFabio, 1993; Jamentz, 1994; Tillema, 1998), empower students to be more actively engaged in the learning process and take control of their own learning (Blake et al. 1995; Paulson et al. 1991;Valeri-Gold, Olson,\& Deming 1991), improve their learning achievement (Winograd, 1995), and provide a continuous and ongoing record of students' progress.

Due to the advancement in information and communication technologies, the use of electronic portfolios has received considerable attention and has become more widespread (Barrett, 2000). Generally speaking, electronic portfolios contain the same types of information as paper portfolios, but the main difference is that electronic portfolios use technologies such in various media form such as CDs, DVDs, the Web, audio, video, graphics, and texts (Abrenica, 2009).

Table 1. The main characteristics of paper-based portfolios and electronic portfolios (adapted from Wanchid, 2011)

\begin{tabular}{lll}
\hline Criteria & Paper-based Portfolios & \multicolumn{2}{l}{ Electronic Portfolios } \\
\hline Place for portfolio development & $\begin{array}{l}\bullet \text { The students work is } \bullet \text { The students work is } \\
\text { assigned, assessed, and stored on } \\
\text { scrapbooks, paper folders, or paper } \\
\text { binders. }\end{array}$ & $\begin{array}{l}\text { assigned, assessed, and stored on } \\
\text { the computer or a website. }\end{array}$ \\
\hline Type of communication & $\bullet \quad$ One way communication & $\begin{array}{l}\text { (without time communication } \\
\text { restrictions) }\end{array}$ \\
\hline
\end{tabular}

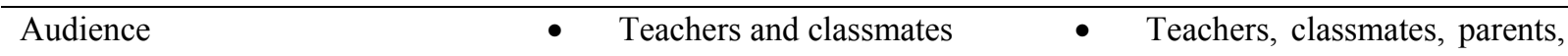
employers, and others

- A privacy feature to limit the audience

\begin{tabular}{|c|c|c|}
\hline Level of interaction & $\begin{array}{l}\text { - Less interaction } \\
\text { negotiation of meaning }\end{array}$ & $\begin{array}{l}\text { - More interaction } \\
\text { negotiation of meaning } \\
\text { unlimited participation online }\end{array}$ \\
\hline Feedback and assessmen & $\begin{array}{l}\text { - Handwritten feedback and } \\
\text { assessment of papers }\end{array}$ & $\begin{array}{l}\text { - Typewritten feedback and } \\
\text { assessment by posting on students' } \\
\text { electronic portfolio website }\end{array}$ \\
\hline Rate of response & $\begin{array}{l}\text { - Less immediate response from } \\
\text { teacher and peers }\end{array}$ & $\begin{array}{l}\text { More immediate response } \\
\text { from teacher and peers }\end{array}$ \\
\hline Com & $\begin{array}{l}\text { - Less support and lack } \\
\text { sense of learning community }\end{array}$ & $\begin{array}{l}\text { - Greater support an } \\
\text { learning community }\end{array}$ \\
\hline
\end{tabular}




\begin{tabular}{|c|c|c|}
\hline Degree of cultural barriers & $\begin{array}{l}\text { - Greater cultural barriers in } \\
\text { terms of face-to-face } \\
\text { communication, peer response } \\
\text { process, and teacher feedback }\end{array}$ & - $\quad$ Fewer cultural barriers \\
\hline Other facilities & - $\quad$ No other facility supports & $\begin{array}{l}\text { - Writing facilitated by } \\
\text { computer technology functions, } \\
\text { such as cutting and pasting. } \\
\text { - Allowing students to collect } \\
\text { and organize their portfolios in } \\
\text { many media such as audio, videos, } \\
\text { graphics, and texts (Barrett, 2005). }\end{array}$ \\
\hline Content permanence & $\begin{array}{l}\text { - Fewer potential feelings of } \\
\text { content permanence }\end{array}$ & $\begin{array}{l}\text { - Greater potential feelings of } \\
\text { content permanence } \\
\text { - High sense of pride, } \\
\text { satisfaction, and accomplishment } \\
\text { (Champbell\& Schmidt, 2005) }\end{array}$ \\
\hline Portability and sharing & $\begin{array}{l}\text { - Difficult to carry to share } \\
\text { - Lost easily and difficult to } \\
\text { retrieve or create the same } \\
\text { documents }\end{array}$ & $\begin{array}{l}\text { - Easy to carry, share, and } \\
\text { transport to a new system (Barrett, } \\
\text { 2005) }\end{array}$ \\
\hline Information accessibility & $\begin{array}{l}\text { - Not convenient for many } \\
\text { readers to access the content at a } \\
\text { time }\end{array}$ & $\begin{array}{l}\text { - Easier to get access to the } \\
\text { content and information for } \\
\text { audience/less time consuming (Al } \\
\text { Khatani, 1999) }\end{array}$ \\
\hline Skills & $\begin{array}{l}\text { - No requirement of computer } \\
\text { literacy skills }\end{array}$ & 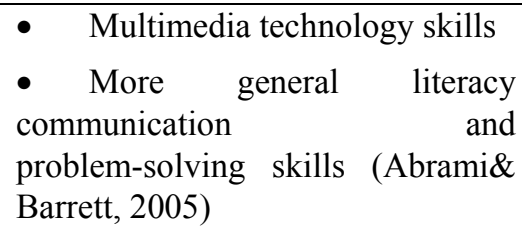 \\
\hline Assessment & $\begin{array}{l}\text { - Inconvenient for both } \\
\text { formative and summative } \\
\text { assessments } \\
\text { - Need more effort to revisit } \\
\text { and refine students' work }\end{array}$ & $\begin{array}{l}\text { - Convenient for formative } \\
\text { assessment } \\
\text { - Revise/adapt teacher's lesson } \\
\text { plan } \\
\text { - Revisit and refine students' } \\
\text { work }\end{array}$ \\
\hline Organization and Maintenance & $\begin{array}{l}\text { - Require physical space for } \\
\text { storage } \\
\text { - Inconvenient to search, edit, } \\
\text { or update. }\end{array}$ & $\begin{array}{l}\text { - Easy to organize, maintain, } \\
\text { search, edit, link, store, reflect on, } \\
\text { and update (Babaee, 2012) }\end{array}$ \\
\hline Cost & $\begin{array}{l}\text { - No extra cost except papers, } \\
\text { files, or folders. } \\
\text { - Other costs such as time and } \\
\text { transportation fees }\end{array}$ & $\begin{array}{l}\text { - Inexpensive after software } \\
\text { installment, but no expenditure if } \\
\text { free weblogs and social networking } \\
\text { sites are used. }\end{array}$ \\
\hline
\end{tabular}

As the English language-learning paradigm has shifted to a learner-centered approach, the learning process of the students has gained considerably attention from educators. In a writing class, the writing instruction and the writing assessment should keep pace with this move. When the process writing approach is employed, a mismatch can be encountered if a writing instructor does not take the writing process of the students into account. It would be meaningless to let the students practice writing many drafts, incorporate feedback, and not reflect on what they learn through these various stages. 
In Table 1, the different characteristics of paper-based portfolios and electronic portfolios are illustrated. It could be said that the advantages of the electronic mode outweigh the traditional mode in various aspects, especially regarding the convenience of portfolio development without place, time, or space restriction. The electronic mode also enhances student-student interaction, provides immediate response from teachers and friends, and facilitates peer feedback activities in the process of writing without face-to-face confrontation, which may lessen the quality of comments from peers due to the Thai culture. The electronic portfolios also serve the different learning styles of the students and the students have a greater sense of pride, satisfaction, accomplishment, and ownership as their work is shown in public. Due to the many outstanding benefits of electronic portfolios in learning, the transition from paper-based portfolios to electronic portfolios seems to have become a reality in EFL learning worldwide. However, a number of previous research results yielded no significantly-different effects of these two different modes regarding the students' learning outcomes (Aliweh, 2012). As a result, more studies are needed to confirm the results and to extend the body of knowledge for English language instruction and assessment. In Thailand, the use of portfolio assessment is limited, especially the tertiary level, and it is less likely to find research on the use of portfolios in writing for business correspondence. Therefore, this research aims to fill this gap, and discusses whether this alternative assessment can be used in English for business writing courses.

\section{Research Objectives}

1) To investigate the effects of the use of paper-based and weblog-based electronic portfolios on the writing achievement of limited English proficiency students

2) To survey the students' attitudes toward the use of the portfolio assessment they experienced

3) To examine whether the students' attitudes toward the portfolios they experienced are significantly different

\section{Research Questions}

1) Are there any significant effects of the use of paper-based portfolios and weblog-based electronic portfolios on the writing achievement of limited English proficiency students?

2) What are the students' attitudes towards the types of portfolios they experienced in the writing class?

3) Are the students' attitudes towards the types of portfolios they experienced significantly different?

\section{Research Hypotheses}

1) There are no significant effects of the use of paper-based portfolios or weblog-based electronic portfolios on the writing achievement of limited English proficiency students at the 0.05 level.

2) The students have positive attitudes towards the type of portfolios they experienced in the writing class.

3) The attitudes of the students towards the types of portfolios they experienced are not significantly different at the 0.05 level.

\section{Method}

The design of this study was experimental and was composed of one control group and one experimental group. The use of different types of portfolios was the independent variable, while writing achievement was the dependent variable of this study. The students in the control group used paper-based portfolios with all of their writing assignments, and writing reflections were hand written, while the students in the experimental group used a weblog for developing their electronic portfolios for their learning and assessment. Both groups were taught with the same instructor using the same teaching methodology, strategies, activities, and materials.

\subsection{Subjects}

The population was 80 Thai second-year undergraduate hotel and service students enrolled in Writing for the Service Industry as a required course at KMUTNB during the second semester of academic year 2014. The students' age range was 20-22. It was assumed that they had limited general English proficiency since they passed English I and II with average grades, ranging from C to D. The samples of this study were 60 students who were randomly selected from the population. According to Krejcie and Morgan (1970), a sufficient sample size with a reliability of $95 \%$ and errors not exceeding $5 \%$, out of 80 as the number of population should be about 66 , but the subject of this study was 60 . However, the sample size is considered sufficient as the minimum of 30 individuals per group is recommended for experimental study (Fraenkel\&Wallen, 2000). As a result, there were 30 students in the control group and 30 students in the experimental group. To ensure that the students in the two groups were homogenous in terms of general English proficiency before the experiment, a mechanical matching design based on the students' average English scores with random group assignment (Fraenkel and 
Wallen, 2000) was utilized. The independent samples t-test and Mann-Whitney U test were used to confirm that the two groups were statistically comparable prior to the treatment.

The instructor had to commute about 3 hours from Bangkok to the Prachinburi campus to teach the course, and the teacher met the students once a week or 3 hours for each group. Out-of-class interaction seldom occurred due to the constraints of this teaching and learning context. However, they have to enroll this required course to meet the requirements of their program curriculum. This course is ESP designed for preparing them to achieve the writing ability for their future career.

\subsection{Instruments and Data Collection}

A writing achievement test, a questionnaire, a semi-structured interview, and reflection were used in the study. The test aimed to measure the students' writing ability before and after taking the course. It was composed of 4 main parts: error identification, error correction, completion, and writing and responding to a complaint letter. The content of the test was related to different text types of writing for business correspondence in the service industry studied in the course. The students had to complete all of the test tasks within 3 hours. For business letter writing part, the assessment criteria for letter writing is divided into four majors writing components: organization, content, appearance, and language use, with each one having four rating level: exemplary, accomplished, developing, and beginning. The analytic scoring was applied as the rubric of evaluation due to its outstanding usefulness, high validity and washback feature (Hyland, 2003). The questionnaire was designed to elicit the students' responses regarding their attitudes toward the type of portfolio that they experienced by using five-point Likert scales ranging from strongly disagree (1) to strongly agree (5). Both of the instruments were distributed to the students at the end of the course. T-test and descriptive statistics were used to analyze the data. A semi-structured interview and writing reflection were applied to gain more in-depth data. The research instrument used in this study was validated by 3 experts and piloted before the main use, and the Index of Item Objective Congruence (IOC) was 1 . The reliability of the questionnaire calculated by Cronbach Coefficient Alpha, SPSS version 11.5, was 0.79.

\subsection{The Experimental Process}

Table 2. The experimental process

\begin{tabular}{lll}
\hline Phases & Activities & Weeks (1-15) \\
\hline I & The course explanation, objectives, and evaluation were 1 \\
introduced to the students. The students in the control group and & \\
the experimental group took the pre-test. \\
- In both control group and experimental group, the use of 2 \\
portfolios was introduced to the students. The objectives, content, \\
and scoring rubric of the portfolios were also discussed and set. \\
- The students in the experimental group were trained in how 3 \\
to construct their personal electronic portfolio by using a weblog, \\
while the students in the control group were trained in how to \\
develop and collect their work in paper-based portfolios. \\
- The students developed their own portfolios by collecting the $4-14$ \\
assignments, writing reflections, and other work such as peer \\
feedback and teacher feedback, first draft, and subsequent drafts \\
of their writing. \\
- The students took the post-test and answered the 15 \\
questionnaire. Additionally, 20 students-ten from the control \\
group and ten from the experimental group-were randomly \\
assigned to the interview session.
\end{tabular}

\subsection{Data Analysis}

6.4.1 In order to answer the first research objective, investigating the effects of paper-based portfolios and weblog-based electronic portfolios on the students' writing achievement, the independent samples t-test analysis was used.

6.4.2 For the second research objective, surveying the students' attitudes towards the type of portfolios they had 
experienced, the mean score of the total sample responses for each item and its Standard Deviation (S.D.) was calculated. Additionally, the data from the open-ended questionnaire and interview were analyzed and categorized under positive responses or negative responses.

6.4.3 For the third research objective, the independent samples t-test analysis was used to examine whether the students' attitudes towards the portfolios they had experienced were significantly different.

\section{Results of the Study}

7.1 The Effects of the Use of Traditional and Electronic Portfolios on the Writing Achievement

Table 3. Results of the writing achievement scores of the students in the control group and experimental group from the t-test analysis

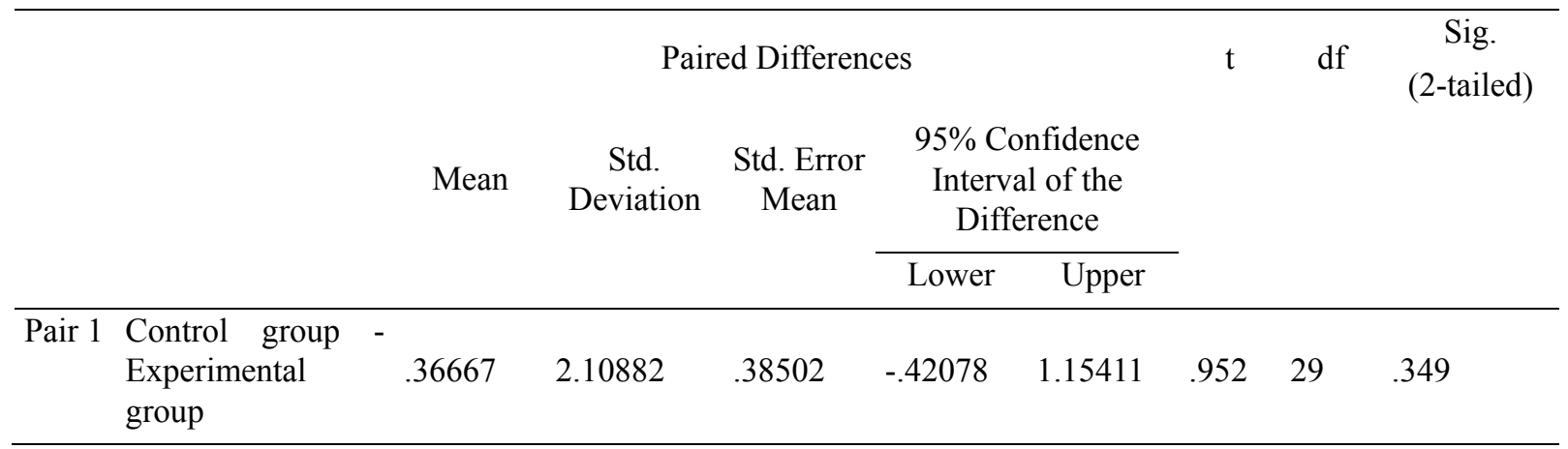

According to the first research objective, which was to investigate the effects of the use of paper-based portfolios and weblog-based electronic portfolios on the writing achievement of limited English proficiency students, the results from the t-test in Table 3 illustrate that the writing achievement scores of the students in the control group and experimental group were not significantly different $(\mathrm{t}=.952, \mathrm{p}>0.05)$.

\subsection{The Students'Attitudes towards the Type of Portfolios They Experienced}

The analyses were based on 26 questionnaire items-13 items focusing on the benefits of using portfolios in the Writing for the Service Industry course, and 13 items asking about their perception of the portfolios they experienced as a tool for assessment. Besides, a five-point Likert scale, ranging from Strongly Disagree (1) to Strongly Agree (5), was used. To make the data more clear, the students' attitudes were interpreted by using the evaluation criteria described below:

0.00-1.50 means that their attitude towards the use of portfolios they

experienced in the Writing for the Service Industry course was very low.

1.51-2.50 means that their attitude towards the use of portfolios they

experienced in the Writing for the Service Industry course was low.

2.51-3.50 means that their attitude towards the use of portfolios they

experienced in the Writing for the Service Industry course was moderate.

3.51-4.50 means that their attitude towards the use of portfolios they

experienced in the Writing for the Service Industry course was high.

4.51-5.00 means that their attitude towards the use of portfolios they

experienced in the Writing for Service Industry course was very high.

The findings were presented in Table 4 and Table 5 respectively. 
Table 4. The students' attitudes towards the benefits of using paper-based portfolios and weblog-based electronic portfolios for learning in the writing course

\begin{tabular}{|c|c|c|c|c|c|c|}
\hline \multirow[t]{2}{*}{ Statement } & \multicolumn{3}{|c|}{ Paper-based portfolios } & \multicolumn{3}{|c|}{$\begin{array}{l}\text { Weblog-based electronic } \\
\text { portfolios }\end{array}$} \\
\hline & $\mathrm{M}$ & S.D. & Meaning & $\mathrm{M}$ & S.D. & Meaning \\
\hline $\begin{array}{l}\text { 1. The use of portfolios is useful when applied } \\
\text { in the writing course. }\end{array}$ & 4.50 & 0.65 & High & 4.43 & 0.76 & High \\
\hline $\begin{array}{l}\text { 2. The use of portfolios makes the writing } \\
\text { course more interesting. }\end{array}$ & 4.15 & 0.67 & High & 4.36 & 0.63 & High \\
\hline $\begin{array}{l}\text { 3. The use of portfolios is convenient for } \\
\text { submitting writing assignments that cover } \\
\text { several drafts. }\end{array}$ & 4.04 & 0.72 & High & 4.64 & 0.50 & $\begin{array}{l}\text { Very } \\
\text { high }\end{array}$ \\
\hline $\begin{array}{l}\text { 4. It is convenient to give and receive feedback } \\
\text { from peers and teachers. }\end{array}$ & 4.15 & 0.73 & High & 4.43 & 0.51 & High \\
\hline $\begin{array}{l}\text { 5. The use of portfolios encourages me to } \\
\text { engage in my own learning. }\end{array}$ & 3.86 & 0.77 & High & 3.92 & 0.84 & High \\
\hline 6. I have fun developing my portfolios. & 4.04 & 1.15 & High & 4.21 & 0.58 & High \\
\hline $\begin{array}{l}\text { 7. I pay more attention to the writing course } \\
\text { than usual when using portfolios. }\end{array}$ & 3.81 & 0.90 & High & 4.14 & 0.66 & High \\
\hline $\begin{array}{l}\text { 8. The use of portfolios increases my learning } \\
\text { engagement out of class time. }\end{array}$ & 4.00 & 0.96 & High & 4.12 & 0.82 & High \\
\hline 9. I am proud of my portfolio. & 4.23 & 0.91 & High & 4.50 & 0.71 & High \\
\hline $\begin{array}{l}\text { 10. The use of portfolios encourages me to use } \\
\text { my creativity. }\end{array}$ & 4.29 & 0.61 & High & 4.31 & 0.84 & High \\
\hline $\begin{array}{l}\text { 11. The use of portfolios can represent my real } \\
\text { self-image and identity. }\end{array}$ & 4.00 & 0.78 & High & 4.08 & 0.89 & High \\
\hline $\begin{array}{l}\text { 12. The use of portfolios encourages me to } \\
\text { take part in my own learning. }\end{array}$ & 4.04 & 0.77 & High & 4.36 & 0.50 & High \\
\hline $\begin{array}{l}\text { 13. The use of portfolios increases my feeling } \\
\text { of work responsibility. }\end{array}$ & 4.57 & 0.51 & $\begin{array}{l}\text { Very } \\
\text { high }\end{array}$ & 4.54 & 0.65 & $\begin{array}{l}\text { Very } \\
\text { High }\end{array}$ \\
\hline
\end{tabular}

According to Table 4, it would appear that the students in both groups had highly positive attitudes towards the type of portfolios they experienced in the writing class, as the mean scores of all the items in the paper-based and weblog-based electronic portfolios were high, ranging from 3.81-4.57 and 3.92-4.64 respectively. The students using the paper-based portfolios highly agreed that the portfolios could increase their feeling of work responsibility (item13, mean $=4.57$ ), the use of portfolios was useful (item 1 , mean $=4.50$ ), and it encouraged them to use their creativity (item 10 , mean $=4.29$ ). Similarly, the students in the weblog-based electronic portfolio group highly agreed that the use of portfolios was convenient for submitting writing assignments (item 3 , mean $=4.64$ ), the portfolios could increase their feeling of work responsibility (item 13 , mean $=4.54$ ), and they were also proud of their portfolios (item 9 , mean= 4.50). 
Table 5. Attitudes towards the use of the portfolios as a tool for assessment in the writing course

\begin{tabular}{|c|c|c|c|c|c|c|}
\hline \multirow{2}{*}{ Statement } & \multicolumn{3}{|c|}{ Paper-based portfolios } & \multicolumn{3}{|c|}{$\begin{array}{l}\text { Weblog-based electronic } \\
\text { portfolios }\end{array}$} \\
\hline & $\mathrm{M}$ & S.D. & Meaning & $\mathrm{M}$ & S.D & Meaning \\
\hline $\begin{array}{l}\text { 1. The use of portfolios encourages me to } \\
\text { assess my own learning progress, weaknesses, } \\
\text { and strengths throughout the course. }\end{array}$ & 4.15 & 0.54 & High & 4.29 & 0.73 & High \\
\hline $\begin{array}{l}\text { 2. I think that the use of portfolio assessment } \\
\text { should be used in other subjects as well. }\end{array}$ & 3.29 & 1.38 & Moderate & 3.85 & 1.19 & High \\
\hline $\begin{array}{l}\text { 3. The portfolio-based assessment can reliably } \\
\text { assess my learning achievement. }\end{array}$ & 4.07 & 0.83 & High & 4.12 & 0.77 & High \\
\hline 4. I prefer testing to portfolio assessment. & 2.21 & 1.31 & Low & 2.23 & 1.39 & Low \\
\hline $\begin{array}{l}\text { 5. The use of portfolios reflects what I have } \\
\text { learned from the writing class. }\end{array}$ & 4.29 & 0.47 & High & 4.19 & 0.49 & High \\
\hline $\begin{array}{l}\text { 6. The clear goals and scoring rubric of the } \\
\text { portfolios help me to be determined in my } \\
\text { learning. }\end{array}$ & 3.86 & 0.66 & High & 3.81 & 0.75 & High \\
\hline $\begin{array}{l}\text { 7. The use of portfolios helps me evaluate my } \\
\text { learning. }\end{array}$ & 4.14 & 0.36 & High & 4.31 & 0.55 & High \\
\hline $\begin{array}{l}8 . \quad \text { I think that the use of portfolios for } \\
\text { assessment in the writing course is fair. }\end{array}$ & 4.07 & 0.47 & High & 4.19 & 0.80 & High \\
\hline $\begin{array}{l}\text { 9. The writing class would be more fun if } \\
\text { testing were solely used for the course } \\
\text { assessment. }\end{array}$ & 1.93 & 1.27 & Low & 2.15 & 1.29 & Low \\
\hline $\begin{array}{l}\text { 10. I think that the use of portfolio assessment } \\
\text { should not be used in the writing course. }\end{array}$ & 1.93 & 1.27 & Low & 1.77 & 0.99 & Low \\
\hline $\begin{array}{l}\text { 11. I can see my learning development from } \\
\text { the use of portfolios. }\end{array}$ & 4.07 & 0.73 & High & 4.19 & 0.80 & High \\
\hline $\begin{array}{l}\text { 12. I feel pressured using portfolios because I } \\
\text { have to compare my work with that of other } \\
\text { friends. }\end{array}$ & 2.23 & 1.39 & Low & 2.21 & 1.31 & Low \\
\hline $\begin{array}{l}\text { 13. I can assess my strengths and weaknesses } \\
\text { through the use of portfolios. }\end{array}$ & 4.14 & 0.53 & High & 4.19 & 0.85 & High \\
\hline
\end{tabular}

In Table 5, thirteen items reflecting the students' attitudes towards the use of portfolios as a tool for assessment are illustrated. The results showed that the students in both groups had highly positive attitudes, as the students believed that portfolios should be used in the writing course rather than focusing on the traditional testing method. The students in both groups highly agreed that the portfolio assessment helped them to assess their own learning progress, weakness, and strength throughout the course. 
7.3 The Comparison of the Attitudes towards the Use of Portfolios by the Students in the Control Group and the Experimental Group

Table 6. Results of the attitudes towards of the students in the control group and experimental group from the t-test analysis

\begin{tabular}{|c|c|c|c|c|c|c|c|c|c|}
\hline & & \multicolumn{5}{|c|}{ Paired Differences } & \multirow[t]{3}{*}{$\mathrm{t}$} & \multirow[t]{3}{*}{$\mathrm{df}$} & \multirow[t]{3}{*}{$\begin{array}{c}\text { Sig. } \\
\text { (2-tailed) }\end{array}$} \\
\hline & & \multirow[t]{2}{*}{ Mean } & \multirow[t]{2}{*}{$\begin{array}{c}\text { Std. } \\
\text { Deviation }\end{array}$} & \multirow[t]{2}{*}{$\begin{array}{l}\text { Std. } \\
\text { Error } \\
\text { Mean }\end{array}$} & \multicolumn{2}{|c|}{$\begin{array}{l}95 \% \text { Confidence } \\
\text { Interval of the } \\
\text { Difference }\end{array}$} & & & \\
\hline & & & & & Lower & Upper & & & \\
\hline *Pair 1 & $\begin{array}{l}\text { Control group } \\
\text { Experimental } \\
\text { group }\end{array}$ & -.18154 & .18206 & .05050 & -.29156 & -.07152 & -3.595 & 12 & .004 \\
\hline $\begin{array}{l}* * \text { Pair } \\
2\end{array}$ & $\begin{array}{l}\text { Control group } \\
\text { Experimental } \\
\text { group }\end{array}$ & -.08615 & .17952 & .04979 & -.19463 & .02233 & -1.730 & 12 & .109 \\
\hline
\end{tabular}

* Pair 1 = Attitudes towards the benefits of using paper-based portfolios and weblog-based electronic portfolios for learning in the writing course.

** Pair 2 = Attitudes towards the use of portfolios as a tool for assessment in the writing course.

The findings illustrate that the attitudes of the students towards the benefits of using paper-based portfolios and weblog-based electronic portfolios for learning in the writing course were significantly different $(\mathrm{t}=-3.595, \mathrm{p}<$ 0.05) while the attitudes of the students toward the use of portfolios as a tool for assessment in the writing course were not significantly different $(t=-1.730, \mathrm{p}>0.05)$.

\section{Discussion}

8.1 Why is there no significant effect of the use of paper-based portfolios and weblog-based electronic portfolios on the writing achievement of limited English proficiency students?

No Impact on Learning the Different Delivery Modes

Although the advantages of electronic portfolios have been claimed by many studies, the results of this research found that after the experiment the students' writing ability in both groups was not significantly different. In other words, it could be said that the different modes of portfolio assessment did not yield different results in this study. Yang and $\mathrm{Xu}$ (2008) emphasized that any types of portfolios have a potential to foster the self-assessment and autonomy of learners. As mentioned in the literature review, the major difference of paper-based and weblog-based electronic portfolios is the mode of work collection, from paper to electronic mode, which can facilitate the learning and assessment process. Portfolios as an alternative assessment tool has its own value, as it fosters intrinsic motivation, responsibility, and ownership, promotes student-teacher interaction, individualizes learning and enriches the uniqueness of each student, provides tangible results of the students' work, facilitates critical thinking, self-assessment, and revision processes, offers chances for collaborative work, and allows assessment of multiple dimensions of language learning (Brown, 2004). Therefore, it is not surprising why differences in the students' scores in the two groups were not reported. The findings of the study also conform to previous research showing that the learning outcomes of students enrolled in web-based instruction and those attending traditional face-to-face classes were not significantly different (Aliweh, 2012; Frydenberg, 2007; Press, 2005). Carnevale (2001) also supported the idea that the delivery mode may not have an impact on the students' learning, but other important factors such as well-designed lessons, instructional methods, and what the students bring to the instructional situation may influence learning.

In this study, although the students' writing ability of the two groups was not significantly different, the average mean scores of the students in the weblog-based electronic portfolios were higher than those of the control group. These results are consistent with previous study conducted by the researcher in 2012 with engineering students in an EAP writing course. The study found that the high, moderate, and low ability students using the electronic 
portfolio significantly gained higher scores. Furthermore, the students in the experimental group wrote longer writing reflections than the students in the other group. The final reflection confirms that the students elaborate their thoughts, are self-directed, and regulate themselves more than in the other group. They could identify their weakness and strengths effortlessly. The results from the interview showed that the students using electronic portfolios seemed to have a greater sense of pride and satisfaction. The distinguishing benefits of the weblog-based electronic portfolios for both teacher and students in this research were that it was easier to submit the portfolios, provide feedback, and provide formative assessment. However, problems of plagiarism were also found in the first few assignments, and writing instructors should make the students aware of the possible penalty and punishment that result when they imitate someone else's work.

However, the results of this study should be carefully considered concerning one important factor that might have affected it; that is, extraneous variables are possible when engaging in online activities, and this possibly impacted the students' writing performance (Phipps \& Merisotis, 1999). Lockee (2001) suggested that as online learning is a very complex process, researchers should analyze and consider many important variables that might impact learning, such as cognitive styles, learning styles, teaching strategies, and teaching methodologies. However, these variables are the least controllable in a research design that focuses on the use of integrated technology in learning (Felix, 2001). In this study, the uncontrollable variable was computer accessibility at home for the students in the control group, and they may have used the computer to search information. In contrast, some students in the weblog-based electronic portfolio group said that they had to do their writing assignments at an Internet café since they did not have the Internet at home. Therefore, significantly different scores of the two groups were not reported.

8.2 Why do the students in both groups have positive attitudes towards the types of portfolios they experienced?

New ways of English language learning and assessment experiences

Regardless of the types of portfolios, the students in the control group and the experimental group had positive attitudes towards the use of portfolio assessment in the Writing for the Service Industry course. This may be due to the fact that portfolio assessment is a new learning experience for EFL students. As the portfolio in this study was used for both learning and assessment, most of the students in both groups highly agreed with its benefits, which was to enhance their learning, to allow them to monitor their own learning progress, and reflect on what they have learnt in the course. Previous research argued that limited English proficiency students seem to have fewer metacognitive strategies, and that portfolios may encourage them to plan, monitor, and organize their learning more effectively. Therefore, the students' English ability improves gradually as they learn how to manage their own learning.

The use of portfolios for language learning also changes the classroom atmosphere to be a more dynamic learning environment that urges students to shift their role from passive learners to active learners. From the students' perspectives, the interview showed that this new learning experience was full of excitement, joy, and fun, and it was definitely different from their previous English learning experience. This conforms to the affective filter hypothesis, which suggests that learners that are bored, unmotivated, unconfident, fearful, or stressed tend to have less success in second language learning (Krashen, 1988).

However, some characteristics of weblog-based electronic portfolios seem to better facilitate the students' learning process and the teacher-student interaction, for example, with the non-restriction of time and place in accessing the portfolio content. Additionally, the results of the interview and the reflection writing supported the idea that the students in the weblog-based electronic portfolio group tended to have a stronger feeling of pride, a greater sense of ownership, more confidence in their computer literacy skills, and were more competitive in improving their work as they could easily access other classmates' electronic portfolios. Furthermore, the students wrote their reflections two or three times longer compared to the control group, and they definitely had more engagement and interaction out of the classroom. Interestingly enough, many students said that their weblog-based electronic portfolios can be used as a good reference for their job application, and they can consult them when they have to write business letters in their future career. However, the only negative comment of the weblog-based electronic portfolio group was from a few students complaining about poor Internet accessibility, so they sometimes had to do their assignments at an Internet café. Additionally, the weblog site was considered a problem for some students in the experimental group since they were not familiar with the weblog platform or application even though a training session was implemented at the beginning of the class.

Concerning the use of portfolios as an alternative form of assessment, the course assessment did not rely on a midterm or final examination, but on the students' portfolios and aspects of their use, including collections of 
their writing assignments, the quality of peer feedback, the revision of writing tasks according to their friends' and teacher's comments, self-assessment, and writing reflection. This new assessment seems to be beneficial for limited proficiency students, as both formative and summative assessments are meaningfully applied. Evidence received from the ongoing assessment of students of limited English ability would be very useful for a teacher in terms of adapting or revising the lessons to suit the students' learning progress.

From the teacher's perspective, as the researcher played the role of teacher in this study, it would appear that the weblog-based electronic portfolios were more convenient than the traditional paper-based portfolios in various aspects, as mentioned in the literature review, especially the levels of teacher-student interactions and the non-restriction of place and time. This was due to the fact that the Writing for the Service Industry course was a 3 -credit required course for second year hotel and tourism students at the Prachinburi campus, located $136 \mathrm{~km}$ from Bangkok. In other words, the teacher had to commute to the Prachinburi campus once a week, so the students in the control group and the experiment group met the teacher only during the class time or 3 hours a week. This meant that the opportunity for face-to-face consultation and interaction was limited. Hence, deployment of communication technology in the class would have been considerably useful in this case. However, it is worth noting that in order to avoid the extraneous variable in terms of the level of teacher interaction, the students in both control and experimental groups were only allowed to call the teacher if it was required.

To summarize, the students in the control group and experimental group had more or less the same positive attitudes towards the use of the type of portfolios they experienced. However, significant different results might have occurred if the students experienced both paper-based and weblog-based electronic portfolios. All in all, based on the results, it could be said that portfolio assessment matches the characteristics of limited English proficiency students.

\section{Pedagogical Implications}

Many courses in tertiary education have integrated computer technology in as a part of the instruction. It cannot be denied that technology skills and "soft" skills such as critical thinking and creative thinking are important and required in the $21^{\text {st }}$ century. The journey of learning or the process of learning however is important as well as the learning outcomes. Portfolios for learning and assessment may be the right "medicine" to be prescribed to illustrate what their learning goals are, what the students learn, how well they learn, how far they have to reach their destination, what they should plan and do to attain their learning objectives, and to reflect their learning and evaluate their own learning journey.

In this study, regardless of the types of portfolios the students experienced, introducing portfolio assessment in a writing course for limited English proficiency students revealed promising results in various aspects, such as improving writing ability, evaluating their own learning, engaging in their learning both inside and outside the classroom, and gaining creative and critical thinking skills. These benefits are less likely to be found in a traditional teacher-centered class with examination-based assessment. Although the use of weblog-based electronic portfolios did not have a significantly different effect on the students' writing achievement scores, some significant advantages of integrating technology in language learning were offered, such as computer literacy skills, the frequency of student-student interaction, and the convenience of providing peer and teacher responses and work submission. However, technological problems such as Internet accessibility and lack of technology skills on the part of the students were of course unavoidable. Therefore, teachers should weigh the pros and cons of the type of the portfolio that is suitable to their teaching and learning context, and it is the teachers' responsibility to design how this learning tool is to be used and how to maximize its potentiality. It could be said that the success or failure of the use of portfolio assessment in a writing class may not depend on the type of portfolios a teacher uses, but it in fact depends on many other factors that should be taken into consideration, especially the teaching and learning contexts, the level of English proficiency of the students, their computer literacy skills, and Internet accessibility.

\section{Conclusion}

In conclusion, the results of this study, both theoretically and practically, shed new light on the area of writing assessment and writing instruction. Although the writing achievement scores of the students in the control group and experimental group were not significantly different, it could be said that the use of portfolios, both traditional paper-based and electronic based types, can effective support for student learning, particularly as regards their positive attitude towards this alternative assessment and their own learning. However, the results of this study should be interpreted with caution, as different results would be yielded if the teaching and learning contexts were different. 


\section{Recommendations for Writing Instructors and Further Research}

1) It is highly recommended that before implementing an unfamiliar new type of assessment in a class such as this one, students should have a crystal clear picture of portfolio assessment and its main purposes; that is, why it is implemented in the writing course. They should be trained in how to develop their personal portfolios, what documents should be collected and how, and how their portfolios are assessed at the beginning the class. However, teachers should be aware of the students' needs and preferences and degree of computer literacy as well.

2) Replication of the study is recommended for a longer period of time to strengthen the results, and further studies should be used with caution in terms of generalization if a small number of subjects is used. Further research should be conducted with students with different English proficiency in order to investigate whether they have different points of view.

3) Other factors that might affect the results of the study, such as gender, age, learning styles, learning strategies, apprehension regarding technology, computer literacy, and group integrity should be taken into consideration.

4) This research was conducted with undergraduate hotel and tourism students that had a limited English proficiency level, so it would be interesting to research the use of different types of portfolios in other ESP courses.

\section{Acknowledgements}

I would like to take this opportunity to show my sincere gratitude to the Faculty of Applied Arts, King Mongkut's University of Technology North Bangkok. Without its financial funding and support, this research would not have been conducted successfully.

\section{References}

Abrenica, Y. (2009). Electronic portfolios. Retrieved December 26, 2008, from http://edweb.sdsu.edu/courses/edtec596r/students/Abrenica.html

Abrami, P. C., \& Barrett, H. (2005). Directions for research and development on electronic portfolios. Canadian Journal of Learning and Technology, 31(3), 1-15.

Aliweh, A. M. (2012). The effect of electronic portfolios on promoting Egyptian EFL college students' writing competence and autonomy. Asian EFL Journal, 13(2), 90-133.

Al, Kahtani, S. (1999). Electronic portfolios in ESL writing: An alternative approach. Computer Assisted Language Learning, 12(3), 261-68. http://dx.doi.org/10.1076/call.12.3.261.5711

Babaee, M. (2012). E-portfolios in social media for facilitating language learning. The Internat journal of Language, Culture, and Society, 29-35.

Babaee, M., \& Tikoduadua, M. (2013). E-portfokios: A new trend in formative writing assessment. International Journal of Modern Education Forum (IJMEF), 2(2), 49-54.

Barrett, H. (2000). Create your own electronic portfolio. Learning and Leading With Technology, 27(7), 14-21.

Barrett, H. (2005). White paper: Researching electronic portfolios and learner engagement. Retrieved December 26, 2012, from http://electronicportfolios.org/reflect/whitepaper.pdf

Barrett, H. (2006). Using electronic portfolios for classroom assessment. Connected Newsletter, 14(2), 4-6.

Blake, I. I. Bachman, K., Frys, M., Holbert, P., Ivan, T., \& Sellitto, P. (1995). A portfolio-based assessment model for teachers: Encouraging professional growth. NASSP Bulletin, 79(573), 37-46. http://dx.doi.org/10.1177/019263659507957307

Brown, H. D. (2004). Language assessment: Principles and classroom practices. White Plains, New York: Longman.

Brown, D. J., \& Hudson, T. (1998). The alternatives on language assessment.Teachers of English to Speakers of Other Languages, 32(4), 653-675. http://dx.doi.org/10.2307/3587999

Campbell, M. I., \& Schmidt, K. J. (2005). Polaris: An undergraduate online portfolio system that encourages personal reflection and career planning. International Journal of Engineering Education, 21(5), 931-942.

Canada, M. (2002). Assessing e-folios in the on-line classes.New Directions for Teaching and Learning, 91, 69-75. http://dx.doi.org/10.1002/tl.68 
Carnevale, D. (2001). Assessment takes center stage in online learning. Chronicle of Higher Education, 443.

Chen, X. (2009). The problem and countermeasure of tourism English Education in vocational colleges. Journal of Shandong University (Philosophy and Social Sciences), 21, 212-215.

Cooper, T., \& Love, T. (2001). "Online portfolios: issues of assessment and pedagogy” In Australian Association for Research in Education conference papers. Retrieved July 29, 2012, from http://www.aare.edu.au/01 pap/coo01346.htm

DeFabio, R. (1993). Characteristics of student performance as factors in portfolioassessment. ERIC Document Reproduction Service No.ED 355556.

Ekbatani, G., \& Pierson, H. (2000). Learner-directed assessment in ESL.Mahwah, NJ: Erlbaum.

Esichaikul, R., \& Baum, T. (1998). The case for government involvement in human resource development: A study of the Thai hotel industry. Tourism Management, 19(4), 359-370. http://dx.doi.org/10.1016/s0261-5177(98)00031-4

Feez, S. (1998). Text-based syllabus design. Sydney, NSW, Australia: Macquarie University.

Felix, U. (2001). Beyond Babel: Language learning online. Melbourne: Language Australia Ltd.

Fraenkel, J. R., \& Wallen, E. N. (2000). How to design and evaluate research in education. New York: McGraw Hill.

Frydenberg, J. (2007). Persistence in University Continuing Education Online Classes. International Review of Research in Open Distance Learning, 8(3), 56-64.

Grabe, W., \& Kaplan, R. B. (1996). Theory \& practice of writing. London: Pearson Education.

Hamp-Lyons, L., \& Condon, W. (2000). Assessing the portfolio: Principles for practice, theory, and research. Cresskill: Hampton Press.

Hyland, K. (2003). Second language writing. Cambridge: Cambridge University Press. http://dx.doi.org/10.1017/CBO9780511667251

Hyland, K. (2007). Genre pedagogy: Language, literacy, and L2 Writing instruction. Journal of Second Language Writing, 16(3), 148-164. http://dx.doi.org/10.1016/j.jslw.2007.07.005

Jamentz, K. (1994). Making sure that assessment improves performance. Educational Leadership, 51(6), 55-57.

Krashen, S. (1988). Second language acquisition and second language learning. London: Prentice-Hall.

Krejcie, R. V., \& Morgan, D. W. (1970). Determining sample size for research activities. Educational and Psychological Measurement, 30, 607-610.

Leong, A., \& Li, J. (2012). A Study on English teaching improvement based on stakeholders' needs and wants: The case of the Faculty of International Tourism of the Macau University of Science and Technology (MUST). Journal of Hospitality, Leisure, Sport \& Tourism Education, 11, 67-78. http://dx.doi.org/10.1016/j.jhlste.2012.02.011

Lipton, R. B. (1997). Electronic student portfolios:A tool for performance-basedassessment (A pilot project in the Berks County Pennsylvania schools). Doctoraldissertation, Nova Southeastern University. UMI Number: 9822205 .

Lockee, B. (2001). What matters in judging distance teaching? The Chronicle of Higher Education. Retrieved December 23, 2007 from http://chronicle.com/free/2001/02/200102210/uhtm

Mitchel, R. (1992). Testing for learning: How new approaches to evaluation can improve American schools. Free Press, New York.

Mohd, R. M. S., \&Mohd, A. M. N. (2007). Malaysian University students' perceptions on the use of portfolio as an assessment tool in an ESL writing classroom. MasalahPendidikan, 30(2), 49-64.

Paulson, F. L., Paulson, P. R., \& Meyer, C. A. (1991). "What Makes a Portfolio a Portfolio?”. Educational Leadership, 58(5), 60-63.

Phipps, R., \& Merisotis, J. (1999). What is the difference? A review of contemporary research on the effectiveness of distance learning in higher education. Retrieved December 23, 2007, from http://www.ihep.org/pubs/pdf/difference/pdf

Press, L. (2005). A Modular Web-based Introductory Course. Retrieved September 10, 2008, from 
http://www.Bpastudio-csudh.edu/fac/Ipree/

Thais' poor English could dim job prospects in ASEAN common market (2015, March 17). The Nation. Retrieved http://www.nationmultimedia.com/national/Thais-poor-English-could-dim-job-prospects-in-Asea-30256167 .html

Tillema, H. H. (1998). Design and validity of a portfolio instrument for professional training. Studies in Educational Evaluation, 24(3), 263-278. http://dx.doi.org/10.1016/s0191-491x(98)00017-0

Tourism Authority of Thailand. Thailand wins best Asia-Pacific destination. Retrieved March 19, 2015, from http://www.tatnews.org/thailand-wins-best-asia-pacific-destination-irish-travel-trade-awards-2014/

Valeri-Gold, M., Olson J. R., \& Deming M. P. (1991). Portfolios: Collaborative authentic assessment opportunities for college developmental learners. Journal of Reading, 35(4), 298-305.

Wanchid, R. (2011). The Use of Electronic Portfolios in the EFL Writing Class: Effects and Student Attitudes. Suthiparithat Journal, 25(76), 167-185.

Wang, S. (2009). E-Portfolios for Integrated Reflection. Issues in Informing Science and Information Technology, $6,449-460$.

Winograd, P. (1995). Putting authentic assessment to work in your classroom. Torrance, CA: The Education Centre.

Yang, W. M., \& Xu, X. Z. (2008). Self-assessment in second language learning.US-China Foreign Language, $6(5), 63-77$.

\section{Copyrights}

Copyright for this article is retained by the author(s), with first publication rights granted to the journal.

This is an open-access article distributed under the terms and conditions of the Creative Commons Attribution license (http://creativecommons.org/licenses/by/3.0/). 